\title{
Effects of day of gestation and feeding regimen in Holstein $\times$ Gyr cows: I. Apparent total-tract digestibility, nitrogen balance, and fat deposition
}

\author{
P. P. Rotta, ${ }^{*}{ }^{1}$ S. C. Valadares Filho, ${ }^{*}$ T. R. S. Gionbelli, ${ }^{*}$ L. F. Costa e Silva, ${ }^{*} \dagger$ T. E. Engle, $\dagger$ M. I. Marcondes, ${ }^{*}$ \\ F. S. Machado, $¥$ F. A. C. Villadiego, ${ }^{*}$ and L. H. R. Silva* \\ *Department of Animal Science, Universidade Federal de Viçosa, Viçosa, Brazil 36571-000 \\ †Department of Animal Science, Colorado State University, Fort Collins 80523 \\ ‡Embrapa Gado de Leite, Juiz de Fora, Brazil 36038-330
}

\section{ABSTRACT}

This study investigated how feeding regimen (FR) alters apparent total-tract digestibility, performance, $\mathrm{N}$ balance, excretion of purine derivatives, and fat deposition in Holstein $\times$ Gyr cows at different days of gestation (DG). Forty-four pregnant multiparous Holstein $\times$ Gyr cows with an average initial body weight of $480 \pm 10.1 \mathrm{~kg}$ and an initial age of $5 \pm 0.5 \mathrm{yr}$ old were allocated to 1 of $2 \mathrm{FR}$ : ad libitum (AL; $\mathrm{n}=20$ ) and maintenance level (ML; $\mathrm{n}=24)$. Maintenance level was considered to be $1.15 \%$ of body weight on a dry matter (DM) basis and met $100 \%$ of the energy requirements, whereas AL provided $190 \%$ of total net energy requirements. Data for hot and cold carcass dressing, fat deposition, average daily gain, empty body gain, and average daily gain without the gravid uterus were analyzed as a $4 \times 2$ factorial design. Intake, apparent total-tract digestibility, $\mathrm{N}$ balance, urinary concentration of urea, and purine derivatives data were analyzed as repeated measurements taken over the $28-\mathrm{d}$ period (122, 150, 178, 206, 234, and $262 \mathrm{~d}$ of gestation). Cows were individually fed a corn silage-concentrate based diet composed of $93 \%$ roughage and $7 \%$ concentrate (DM basis) as a total mixed ration. Pregnant cows were slaughtered on 4 different DG: $139(\mathrm{n}=11), 199$ ( $\mathrm{n}=$ 11), $241(\mathrm{n}=11)$, and $268 \mathrm{~d}(\mathrm{n}=11)$. Overall, DM intake decreased as DG increased. This decrease observed in DM intake may be associated with the reduction in ruminal volume caused by the rapid increase in fetal size during late gestation. We observed an interaction for DM and organic matter apparent total-tract digestibility between FR and DG; at 150, 178, and $206 \mathrm{~d}$ of gestation, ML-fed cows had greater DM and organic matter apparent total-tract digestibility values than AL-fed cows. Rib fat thickness, mesentery, and kidney, pelvic, and heart fat were greater in AL-fed than

Received April 24, 2014.

Accepted January 11, 2015.

${ }^{1}$ Corresponding author: polyana.rotta@ufv.br in ML-fed cows at all DG, with the exception of rib fat thickness on d 139. Ad libitum-fed cows excreted more $\mathrm{N}$ in their feces and urine compared with ML-fed cows. Pregnant cows that were fed at maintenance had greater digestibility during some DG, excreted less $\mathrm{N}$ in feces and less $\mathrm{N}$ and urea in urine, and deposited less fat in the body. We therefore recommend ML $(1.15 \%$ of body weight with $93 \%$ of roughage) as a FR for pregnant dry cows; however, during the last month of gestation, AL seems to be the most appropriate FR to avoid loss of body weight.

Key words: ad libitum, maintenance, $\mathrm{N}$ balance, performance

\section{INTRODUCTION}

According to the NRC (2001), DMI is an important factor in nutrition because it establishes the amount of nutrients that are available for maintenance and production. Underfeeding nutrients can restrict production and may affect the pregnancy (Vonnahme et al., 2007). Moreover, feeding in excess of requirements increases feed costs (Herd et al., 2003) and may result in increased excretion of nutrients into the environment (Nennich et al., 2006) and fat deposition (Rincker et al., 2008; Duarte et al., 2013).

Some studies have demonstrated that DMI decreases during late gestation (Dorshorst and Grummer, 2002; Hayirli and Grummer, 2004; French, 2006); however, most of these experiments have used Holstein, and thus, information for Holstein $\times$ Gyr cows is lacking. The Gyr cattle breed (Bos indicus) is important because of its tolerance to heat and parasites, its rusticity, and its adaptation to the tropics (Silva et al., 2011; Santana et al., 2014). Also, a considerable amount of data describing changes in voluntary DMI of Holstein cows during the prepartum period is available (Hayirli et al., 2002, 2003). However, information regarding DMI of Holstein $\times$ Gyr cows during gestation is lacking.

Limit feeding has been shown to increase diet digestibility compared with animals with ad libitum (AL) ac- 
cess to feed (Galyean et al., 1979; Murphy et al., 1994; Clark et al., 2007). However, no study has been conducted using pregnant Holstein $\times$ Gyr cows to evaluate diet digestibility during early, mid, and late gestation of cows that are fed at maintenance level (ML) or with AL access to feed.

Our hypothesis was that cows could be fed at ML throughout the gestation period without changing the apparent total-tract digestibility and carcass characteristics, and resulting in a $\mathrm{N}$ balance close to zero (Eriksson et al., 2004). Our objectives in this study, therefore, were to investigate the influence of day of gestation (DG) and feeding regimen (FR) on apparent total-tract digestibility, performance, $\mathrm{N}$ balance, and fat deposition in Holstein $\times$ Gyr cows.

\section{MATERIALS AND METHODS}

All animal care and handling procedures were approved by the Animal Care and Use Committee of the Department of Animal Science of the Universidade Federal de Viçosa, Viçosa, Minas Gerais, Brazil, before initiation of the experiment.

\section{Animals and Management}

A vaginal progesterone insert [controlled internal drug release (CIDR), Zoetis, Madison, NJ] was used for $7 \mathrm{~d}$ in unsuckled, multiparous Holstein $\times$ Gyr cows $(\mathrm{n}=120)$ to synchronize estrus, after which a $\mathrm{PGF}_{2 \alpha}$ injection (25 mg, Lutalyse, Zoetis) was administered upon CIDR removal. Cows were monitored for estrus every $12 \mathrm{~h}$ and were artificially inseminated by using semen from a single Holstein bull $12 \mathrm{~h}$ after estrus. On d 40 of gestation, cows were housed in $30-\mathrm{m}^{2}$ individual pens, of which $8 \mathrm{~m}^{2}$ was covered with concrete floors and equipped with individual feed bunks and an automatic water system. On d 60 of gestation, the pregnancy was verified by palpating, fetal sexing was performed by using transrectal ultrasound (Aloka 500 with a $5-\mathrm{MHz}$ linear probe, Aloka, Wallingford, CT), and 44 cows were randomly selected for this experiment. The diets were provided from d 60 of gestation until cows reached the previously designated DG.

Forty-four multiparous dry Holstein $\times$ Gyr cows with an average initial BW of $480 \pm 10.1 \mathrm{~kg}$ and an age of 5 $\pm 0.5 \mathrm{yr}$ were allocated to 1 of $2 \mathrm{FR}$ : AL $(\mathrm{n}=20)$ or ML $(\mathrm{n}=24)$. The cows used in this experiment were chosen in an attempt to represent the average age of cows raised in Brazil (IBGE, 2009). Maintenance was considered to be $1.15 \%$ of $\mathrm{BW}$ according to a previous study conducted by our research group (Duarte et al., 2013). The average milk production of the last lactation was $12.1 \pm 1.25 \mathrm{~L} / \mathrm{d}$ for AL-fed cows and $12.8 \pm$
$1.11 \mathrm{~L} / \mathrm{d}$ for ML-fed cows. The AL-fed cows had an average number of lactations of $2.7 \pm 0.20$ and that for the ML-fed cows was $2.8 \pm 0.16$ lactations. Every $28 \mathrm{~d}$, cows were weighed in the morning before feeding and after a 16-h fast to obtain the shrunk BW. The shrunk BW was estimated after collecting all of the feed in the feeders, $16 \mathrm{~h}$ before weighing, to standardize the BW. Feed intake was adjusted based on values of shrunk BW to maintain ML throughout the entire gestation period.

To evaluate the effects of different DG, pregnant cows were slaughtered at 4 DG. Each FR group was randomly divided into 4 groups, with 5 cows from AL and 6 cows from ML slaughtered at 139, 199, 241, and $268 \mathrm{~d}$ of gestation. However, 1 abortion was verified in a cow from the ML treatment at $139 \mathrm{~d}$. Thus, data from 43 cows were used for analyses, and 5 ML cows were evaluated at $139 \mathrm{~d}$ of gestation.

Cows were fed corn silage and a concentrate-based diet at a ratio of 93:7 on a DM basis as a TMR twice daily, with $60 \%$ of the amount offered in the morning and $40 \%$ in the afternoon feeding (DM basis). The composition of the experimental diet is presented in Table 1. The amounts of corn silage and concentrate that were supplied were recorded daily. To allow AL cows ad libitum access to feed, feed delivery was adjusted to allow approximately $5 \%$ orts daily on an as-fed basis. All cows had ad libitum access to water. Corn silage was sampled daily and stored at $-20^{\circ} \mathrm{C}$ until analyzed. Corn silage samples were dried weekly in a forced-air drying oven at $55^{\circ} \mathrm{C}$ for $72 \mathrm{~h}$ and ground through a 1-mm screen (Wiley mill, A. H. Thomas, Philadelphia, PA) for further analysis.

\section{Urine and Fecal Measurements}

In the present study, we had 6 periods of spot fecal and urine collections and each period lasted 28 d. For evaluation of apparent total-tract digestibility, feces from all cows were collected during the last $5 \mathrm{~d}$ of each 28 -d period. Fecal collections were performed at 0600 , 0900, 1200, 1500, and $1800 \mathrm{~h}$ on d 1, 2, 3, 4, and 5, respectively. Samples of approximately $200 \mathrm{~g}$ were collected by rectal stimulation or as the animal defecated. Feces were dried in a forced-air drying oven at $55^{\circ} \mathrm{C}$ for $72 \mathrm{~h}$ and then ground through a 1-mm screen (Wiley mill, A. H. Thomas). A composite sample was obtained per collection period for each cow by utilizing $15 \mathrm{~g}$ of the dried and ground sample per collection time. Indigestible neutral detergent fiber (iNDF) was used as an internal marker to estimate total fecal excretion (Lippke et al., 1986).

Spot urine samples were collected at 0600 and $1500 \mathrm{~h}$ on d 1 and 4 of each 28-d period, respectively, with d 1 
Table 1. Ingredients and chemical composition (means \pm SD) of feed

\begin{tabular}{lc}
\hline Item & \% of DM \\
\hline Ingredients & \\
Corn silage & 93.0 \\
Cotton meal & 5.0 \\
Limestone & 0.5 \\
Salt & 0.5 \\
Urea & 0.9 \\
Ammonium sulfate & 0.1 \\
Mineral mix ${ }^{1}$ & 0.02 \\
Chemical composition & \\
DM, \% & $37.6 \pm 0.36$ \\
OM & $92.9 \pm 0.60$ \\
CP & $11.1 \pm 0.12$ \\
NDF & $49.7 \pm 0.29$ \\
Ether extract & $3.7 \pm 0.06$ \\
NFC & $28.4 \pm 0.21$ \\
Indigestible NDF & $15.7 \pm 0.16$ \\
\hline
\end{tabular}

${ }^{1}$ Mineral mix composition $=29.2 \mathrm{~g} / \mathrm{kg}$ of calcium, $0.70 \mathrm{~g} / \mathrm{kg}$ of phosphorus, $2.11 \mathrm{~g} / \mathrm{kg}$ of magnesium, $0.89 \mathrm{~g} / \mathrm{kg}$ of potassium, $0.31 \mathrm{~g} / \mathrm{kg}$ of sodium, $63.5 \mathrm{~g} / \mathrm{kg}$ of sulfur, $348 \mathrm{mg} / \mathrm{kg}$ of cobalt, $2.56 \mathrm{mg} / \mathrm{kg}$ of chromium, $3,296 \mathrm{mg} / \mathrm{kg}$ of copper, $2,088 \mathrm{mg} / \mathrm{kg}$ of iron, $4,673 \mathrm{mg} / \mathrm{kg}$ of manganese, $7,817 \mathrm{mg} / \mathrm{kg}$ of zinc, and $318 \mathrm{mg} / \mathrm{kg}$ of selenium.

considered to be the first day of the period composed of $28 \mathrm{~d}$. Urine samples were taken midstream after manual stimulation of the vulva, acidified to a $\mathrm{pH}<4.0$ with concentrated sulfuric acid to prevent $\mathrm{NH}_{3}$ volatilization, and then frozen at $-20^{\circ} \mathrm{C}$ for further analyses of $\mathrm{N}$, urea, allantoin, creatinine, and uric acid.

\section{Slaughter and Laboratory Analyses}

Preharvest handling of animals was in accordance with good animal welfare practices, and slaughtering procedures followed the Sanitary and Industrial Inspection Regulation for Animal Origin Products (Brasil, 1997). Feed was withheld overnight but cows had ad libitum access to water. Cows were slaughtered at Universidade Federal de Viçosa by captive bolt stunning and subsequent exsanguination. The gravid uterus was immediately collected and weighed. Maternal mesentery was removed from the reticulum-rumen, omasum, abomasum, and small and large intestines; and kidney, pelvic, and heart fat (KPH) were removed before splitting and weighing the carcass. The left half of the carcass was weighed and cooled in a cold chamber at $4^{\circ} \mathrm{C}$ for $24 \mathrm{~h}$. After cooling, carcasses were weighed to evaluate the cold carcass weight and cold carcass dressing percentage. The 12th-rib fat thickness was taken at three-quarters of the length ventrally over the longissimus muscle (Greiner et al., 2003).

Corn silage, ingredients in concentrate, and feces were analyzed for DM, OM, and $\mathrm{N}$ concentrations (AOAC International, 2000; method numbers 934.01 for DM, 930.05 for OM, and 981.10 for N). Ether extract (EE) was analyzed according to the method described by AOAC International (2006). Neutral detergent fiber was determined according to the technique described by Mertens et al. (2002) without the addition of sodium sulfite, but with the addition of thermostable $\alpha$-amylase to the detergent (Ankom Technology Corp., Fairport, NY).

The concentration of iNDF was quantified in triplicate for corn silage, feed, and fecal samples. The samples that were used to quantify iNDF were ground in a knife mill with a 2-mm sieve (Valente et al., 2011). Samples of $1.5 \mathrm{~g}$ were added to preweighed polyester bags with a pore size of $12 \mu \mathrm{m}$ and a pore area equal to $6 \%$ of the total surface (Saatifil PES 12/6, Saatitech S.p.A., Veniano, Como, Italy). The bags were incubated for 288 $\mathrm{h}$ in the rumens of 2 cannulated bulls that were fed a diet consisting of $50 \%$ corn silage and $50 \%$ concentrate on a DM basis at the maintenance level. After removal from the rumen, the bags were rinsed in a household washing machine, dried at $55^{\circ} \mathrm{C}$ for $48 \mathrm{~h}$, and weighed. Residues were then analyzed for NDF in an Ankom 200/220 Fiber Analyzer (Ankom Technology Corp.). Heat-stable $\alpha$-amylase (Mertens et al., 2002) was used in the determination of NDF. Nonfiber carbohydrates were calculated according to Detmann and Valadares Filho (2010), where NFC $(\%)=100-[\% \mathrm{CP}-(\% \mathrm{CP}$ derived from urea $+\%$ urea $)+\% \mathrm{NDF}+\% \mathrm{EE}+$ $\%$ ash]. The content of TDN was estimated based on the following equation: digestible $\mathrm{CP}+2.2$ digestible $\mathrm{EE}+$ digestible NDF + digestible NFC (NRC, 2001). Allantoin, creatinine, and uric acid were analyzed by using an HPLC (Agilent 1100 series, Agilent Technologies, Waldbronn, Germany) as previously described by Czauderna and Kowalczyk (2000), with modifications by George et al. (2006).

\section{Estimation of Purine Derivatives}

The equations outlined below were used to estimate the excretion of purine derivatives (PD) and have been described previously (Chen, 1989; Verbic et al., 1990; Chen et al., 1995). To estimate microbial N supply based on urinary excretion of $\mathrm{PD}$, the $\mathrm{PD}$ index was calculated based on total PD [allantoin $(\mathrm{mmol} / \mathrm{L})$ $+\operatorname{uric}$ acid $(\mathrm{mmol} / \mathrm{L})]$ where $\mathrm{PD}$ index $=\{$ total $\mathrm{PD}$ $(\mathrm{mmol} / \mathrm{L})] /$ creatinine $(\mathrm{mmol} / \mathrm{L})\} \times \mathrm{BW}^{0.75}$. The excretion of creatinine $\left(\mathrm{mmol} / \mathrm{kg}\right.$ of $\left.\mathrm{BW}^{0.75}\right)$ was extrapolated by using the estimated daily urinary volume (L), as calculated from the equation by Pacheco et al. (2009). The estimated urinary creatinine excretion $(0.9 \mathrm{mmol} / \mathrm{kg}$ of $\mathrm{BW}^{0.75}$ ) was included in the following equation to estimate the daily excretion of $\mathrm{PD}\left(\mathrm{mmol} / \mathrm{kg}\right.$ of $\left.\mathrm{BW}^{0.75}\right)$ : daily excretion of $\mathrm{PD}\left(\mathbf{d P D} ; \mathrm{mmol} / \mathrm{kg}\right.$ of $\left.\mathrm{BW}^{0.75}\right)=$ 
PD index $\times 0.90$. From this, the amount of purines that were absorbed daily was estimated: daily absorbed purines $(\mathbf{d a P})=\left[\mathrm{dPD}\left(\mathrm{mmol} / \mathrm{kg}\right.\right.$ of $\left.\mathrm{BW}^{0.75}\right)-0.385$ $\left.\times \mathrm{BW}^{0.75}\right]+0.85$; microbial $\mathrm{N}(\mathrm{g}$ of $\mathrm{N} / \mathrm{d}$ ) supply was determined by using the following equation: microbial $\mathrm{N}(\mathrm{g}$ of $\mathrm{N} / \mathrm{d})=(\mathrm{daP} \times 70) /(0.116 \times 0.83 \times 1,000)$.

\section{Statistical Analysis}

Data on hot and cold carcass dressing, rib fat thickness, fat deposition, ADG, empty BW gain, and ADG without the gravid uterus were analyzed as a $4 \times 2$ factorial design by using PROC MIXED (SAS Inst. Inc., Cary, NC) and the following model:

$$
\mathrm{Y}_{\mathrm{ijk}}=\mu+\mathrm{F}_{\mathrm{i}}+\mathrm{D}_{\mathrm{j}}+(\mathrm{F} \times \mathrm{D})_{\mathrm{ij}}+\mathrm{e}_{\mathrm{ijk}},
$$

where $\mathrm{Y}_{\mathrm{ijk}}=$ the dependent variable, $\mu=$ the overall mean, $F_{i}=$ the effect of FR i, $D_{j}=$ the effect of DG $j$, $\mathrm{F} \times \mathrm{D}=$ the interaction between $\mathrm{FR}$ and $\mathrm{DG}$, and $\mathrm{e}_{\mathrm{ijk}}$ $=$ the random error associated with $\mathrm{Y}_{\mathrm{ijk}}$.

Intake, apparent total-tract digestibility, $\mathrm{N}$ balance, urinary concentration of urea, and PD data were analyzed as repeated measurements taken over the 28-d period by using the PROC MIXED (SAS Inst. Inc., Cary, NC) and the following model:

$$
\begin{gathered}
\mathrm{Y}_{\mathrm{ijklm}}=\mu+\mathrm{F}_{\mathrm{i}}+\mathrm{D}_{\mathrm{j}}+(\mathrm{F} \times \mathrm{D})_{\mathrm{ij}}+\mathrm{e}_{\mathrm{ijk}}+\mathrm{M}_{\mathrm{l}} \\
+(\mathrm{F} \times \mathrm{M})_{\mathrm{il}}+(\mathrm{D} \times \mathrm{M})_{\mathrm{j} 1}+(\mathrm{F} \times \mathrm{D} \times \mathrm{M})_{\mathrm{ijl}}+\mathrm{e}_{\mathrm{ijklm}},
\end{gathered}
$$

where $Y_{\mathrm{ijklm}}=$ the dependent variable, $\mu=$ the overall mean, $F_{i}=$ the effect of FR i, $D_{j}=$ the effect of DG j, F $\times \mathrm{D}=$ the interaction between $\mathrm{FR}$ and $\mathrm{DG}, \mathrm{F} \times \mathrm{M}=$ the interaction between FR and time of measurement, $\mathrm{D} \times \mathrm{M}=$ the interaction between $\mathrm{DG}$ and time of measurement, $\mathrm{F} \times \mathrm{D} \times \mathrm{M}=$ the interaction among $\mathrm{FR}$, $\mathrm{DG}$, and time of measurement, and $\mathrm{e}_{\mathrm{ijk}}=$ the random error associated with the replicate of $\mathrm{F}$ within $\mathrm{D}, \mathrm{M}_{1}=$ the effect of time of measurement 1 , and $\mathrm{e}_{\mathrm{ijklm}}=$ random error associated with $\mathrm{Y}_{\mathrm{ijk} k \mathrm{~m}}$.

The DG and FR were considered the fixed effects for repeated measurements taken over the $28-\mathrm{d}$ period, and cows were considered to be the random effect. Distinct residual variances were modeled by using the command REPEATED. A heterogeneous autoregressive 1 was used. The PDIFF option, adjusted by the Tukey method, was included in the LSMEANS statement to account for multiple comparisons. Least squares means were estimated for all effects and were compared by using Tukey's method at $\alpha=0.10$. A quadratic regression was performed for DMI expressed as grams per kilogram of $\mathrm{BW}$ during $\mathrm{DG}$ by using data from $\mathrm{AL}$ cows to provide an equation to predict DMI.

\section{RESULTS}

\section{Feed Intake}

Holstein $\times$ Gyr cows with $\mathrm{AL}$ access to feed had greater $(P<0.01)$ DMI expressed as kilogram per day at 150 and 178 d compared with DMI at 234 and 262 $\mathrm{d}$ of gestation (Table 2). Given that the average gestation period for these cows is approximately $284 \mathrm{~d}$ (Mellado et al., 2011), we observed that DMI decreased from $50 \mathrm{~d}$ before parturition. Dry matter intake at 262 $\mathrm{d}$ in Holstein $\times$ Gyr cows was approximately $22 \%(P$ $<0.01)$ less than at $234 \mathrm{~d}$. No difference $(P=0.27)$ was observed in DMI in ML-fed cows during gestation, and this may be because they were weighed every 28 $\mathrm{d}$ and DMI was adjusted to $1.15 \% \mathrm{BW}$. Moreover, in all DG that were studied, DMI was greater $(P=0.03)$ in AL-fed cows compared with ML-fed cows. However, at $262 \mathrm{~d}$ of gestation, treatment did not influence $(P=$ $0.43)$ DMI when it was analyzed as a percentage of BW (Figure 1). When using the percentage of BW to evaluate DMI, we observed no difference $(P=0.74)$ at 122 , 150,178 , and $206 \mathrm{~d}$ of gestation in AL-fed cows (Figure $1)$. However, these DG were different $(P<0.01)$ from those observed at 234 and $262 \mathrm{~d}$, and the lowest $(P$ $<0.01$ ) value was observed in cows at $262 \mathrm{~d}$ of gestation (Figure 1). Organic matter, $\mathrm{CP}$, and NDF intakes were also less $(P<0.01)$ in AL-fed cows at 234 and $262 \mathrm{~d}$ than those at 150 and $178 \mathrm{~d}$ of gestation (Table 2 ). Figure 2 illustrates DMI expressed as grams per kilogram of BW in AL-fed cows from 118 until $262 \mathrm{~d}$ of gestation. In addition, an estimated equation to predict DMI in pregnant dry cows is presented: DMI $(\mathrm{g} / \mathrm{kg}$ of $\mathrm{BW})=-0.0007 \mathrm{~d}^{2}+0.189 \mathrm{~d}+9.3942$, where $\mathrm{d}=$ days of gestation (122 to $262 \mathrm{~d}$ ).

\section{Apparent Total-Tract Digestibility}

Dry matter and OM apparent total-tract digestibility had a significant interaction effect $(P=0.03)$ between FR and DG. Maintenance fed cows showed greater $(P$ $<0.01) \mathrm{DM}$ and OM apparent total-tract digestibility than AL-fed cows at 150,178, and $206 \mathrm{~d}$ of gestation. However, at 122, 234, and $262 \mathrm{~d}$ of gestation, DM and OM apparent total-tract digestibility were similar $(P$ $=0.42)$ between ML- and AL-fed cows. We observed the lowest $(P<0.01)$ value of DM apparent total-tract digestibility in ML- and AL-fed cows at 234 and $262 \mathrm{~d}$ of gestation.

An interaction $(P=0.03)$ was observed for $\mathrm{CP}$ apparent total-tract digestibility between FR and DG. Both AL- and ML-fed cows showed the greatest $(P=$ $0.03)$ value in $\mathrm{CP}$ apparent total-tract digestibility at $122 \mathrm{~d}$ (Table 3 ). These results are similar to those re- 


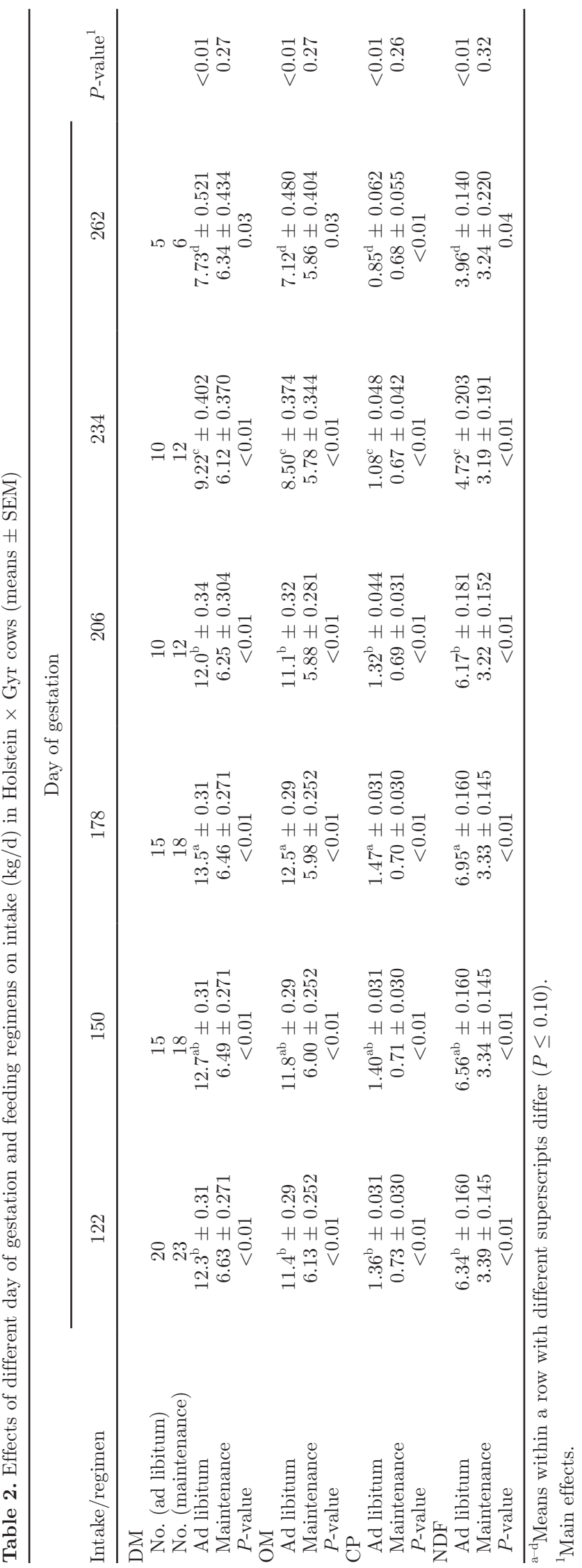

ported for DM apparent total-tract digestibility, where the decrease in digestibility began at $150 \mathrm{~d}$ of gestation. However, no difference $(P=0.24)$ for $\mathrm{CP}$ apparent total-tract digestibility was observed at 150, 178, 206, 234, or 262 d of gestation.

No difference $(P=0.19)$ was observed for NDF apparent total-tract digestibility interaction between FR and DG (Table 3). However, we observed differences $(P<0.01)$ between FR: the greatest $(P<0.01)$ value of NDF apparent total-tract digestibility was detected in ML-fed cows. Also, the greatest $(P<0.01)$ NDF apparent total-tract digestibility value was observed in cows at $122 \mathrm{~d}$ of gestation, and the lowest $(P<0.01)$ value was observed at $262 \mathrm{~d}$. Intermediate $(P<0.01)$ values were observed in cows at 150,178, 206, and 234 d of gestation.

\section{Nitrogen Balance}

No difference $(P=0.54)$ was observed in mass of $\mathrm{N}$ excretion in the urine of AL-fed cows for the different DG that were evaluated (Figure 3). Nevertheless, N intake was less $(P<0.01)$ at 234 and $262 \mathrm{~d}$ than at 122 , 150,178 , and $206 \mathrm{~d}$ of gestation. Nitrogen excreted in feces was less $(P<0.01)$ at 234 and $262 \mathrm{~d}$ than at 122 , 150,178 , and $206 \mathrm{~d}$ of gestation in AL-fed cows, and it was similar $(P=0.36)$ to that of ML-fed cows (Figure $3)$. Nitrogen excreted in feces was greater $(P<0.01)$ in AL- than ML-fed cows at 122, 150, 178, 206, and $234 \mathrm{~d}$ of gestation (Figure 3). However, at $262 \mathrm{~d}$ of gestation, we observed similar $(P=0.21)$ estimates in AL- and ML-fed cows. This can be explained by the similar DMI expressed as percentage of BW at $262 \mathrm{~d}$ of gestation for the $2 \mathrm{FR}$ (Figure 1). For AL-fed cows, the lowest $(P<0.01)$ value of $\mathrm{N}$ balance was observed at $262 \mathrm{~d}$ of gestation (Figure 3).

\section{Excretion of Purine Derivatives}

The values for urea, allantoin, uric acid, absorbed purines, microbial $\mathrm{N}$, and microbial efficiency are presented in Table 4. Allantoin, uric acid, and absorbed purines were greater $(P<0.01)$ in AL- than ML-fed cows. However, no difference $(P=0.18)$ was observed for microbial efficiency expressed as gram of $\mathrm{CP}$ per kilogram of TDN between AL- and ML-fed cows. The DG influenced $(P=0.02)$ uric acid.

\section{Carcass Characteristics, Fat Deposition, and Performance}

Final BW and empty BW were heavier $(P<0.01)$ in AL- than in ML-fed cows (Table 5). Although no difference $(P=0.21)$ was observed in final $\mathrm{BW}$ for the 


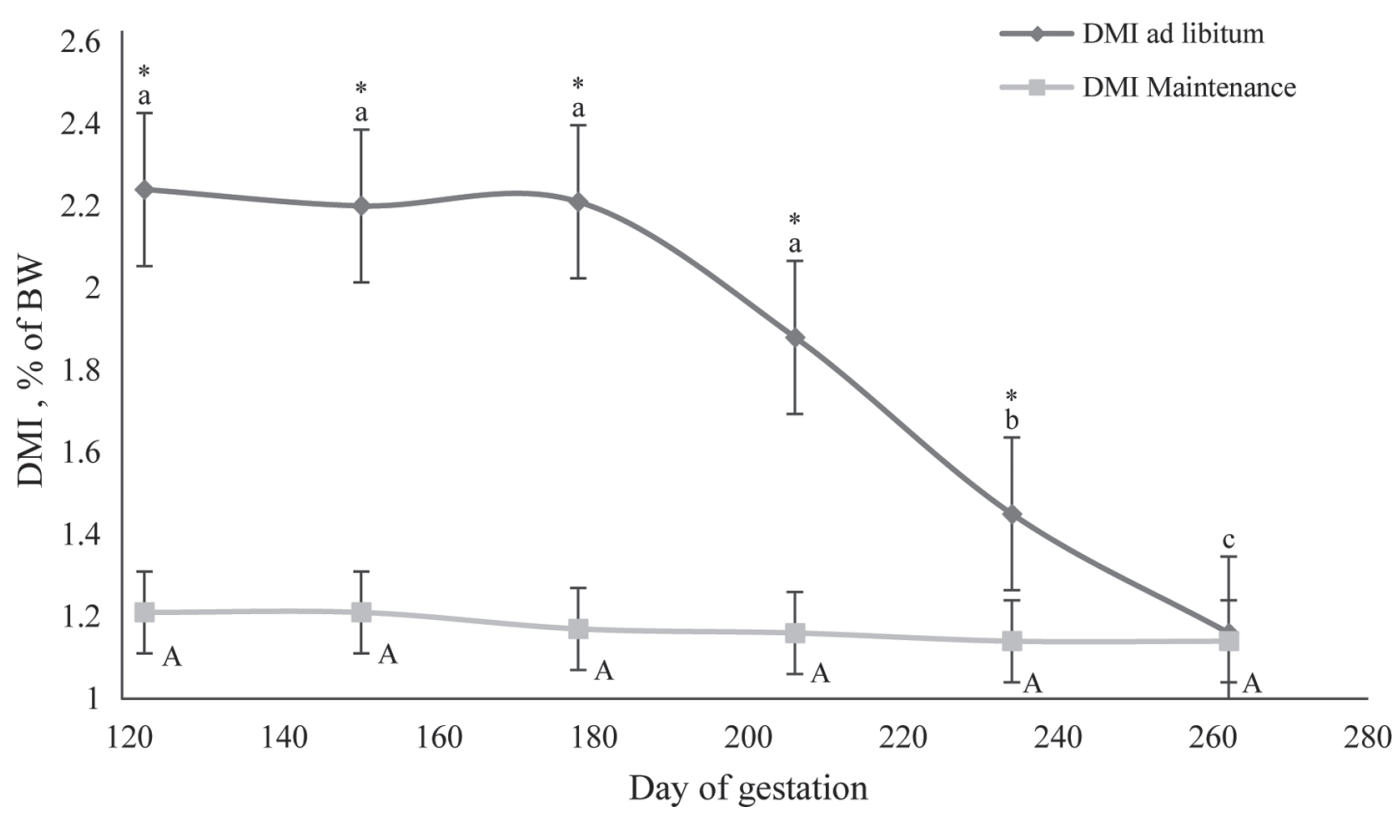

Figure 1. Dry matter intake calculated as percentage of BW in cows fed ad libitum and maintenance levels during gestation. Results are means $\pm \mathrm{SEM}$; *different at $P \leq 0.10$ between feeding regimens. Different lowercase letters are different at $P \leq 0.10$ for ad libitum diets; different uppercase letters are different at $P \leq 0.10$ for maintenance diets.

different DG, we observed a lesser $(P=0.02)$ empty BW in cows at 139 and $199 \mathrm{~d}$ of gestation. No difference $(P=0.27)$ was observed for hot carcass and cold carcass dressings between the FR that were evaluated. However, differences $(P<0.01)$ were observed when comparing DG. Heavier $(P<0.01)$ values for hot carcass and cold carcass dressings were observed at 139, 199, and $241 \mathrm{~d}$ than at $268 \mathrm{~d}$ of gestation.

Rib fat thickness was greater $(P=0.04)$ in AL- than ML-fed cows during gestation, with an exception at
$139 \mathrm{~d}$ (Figure 4). Differences in rib fat thickness $(P=$ 0.08 ) were also observed for DG; the greatest value was observed in cows at $268 \mathrm{~d}$ followed by 199 and $241 \mathrm{~d}$, whereas the lowest value was observed in cows at $139 \mathrm{~d}$ of gestation in AL-fed cows.

Mesentery tissue mass, expressed as kilograms or grams per kilogram of empty BW, was heavier $(P<$ 0.01) in AL- than in ML-fed cows (Figure 4). Day of gestation influenced $(P=0.01)$ mesentery tissue mass expressed as kilograms or grams per kilogram of empty

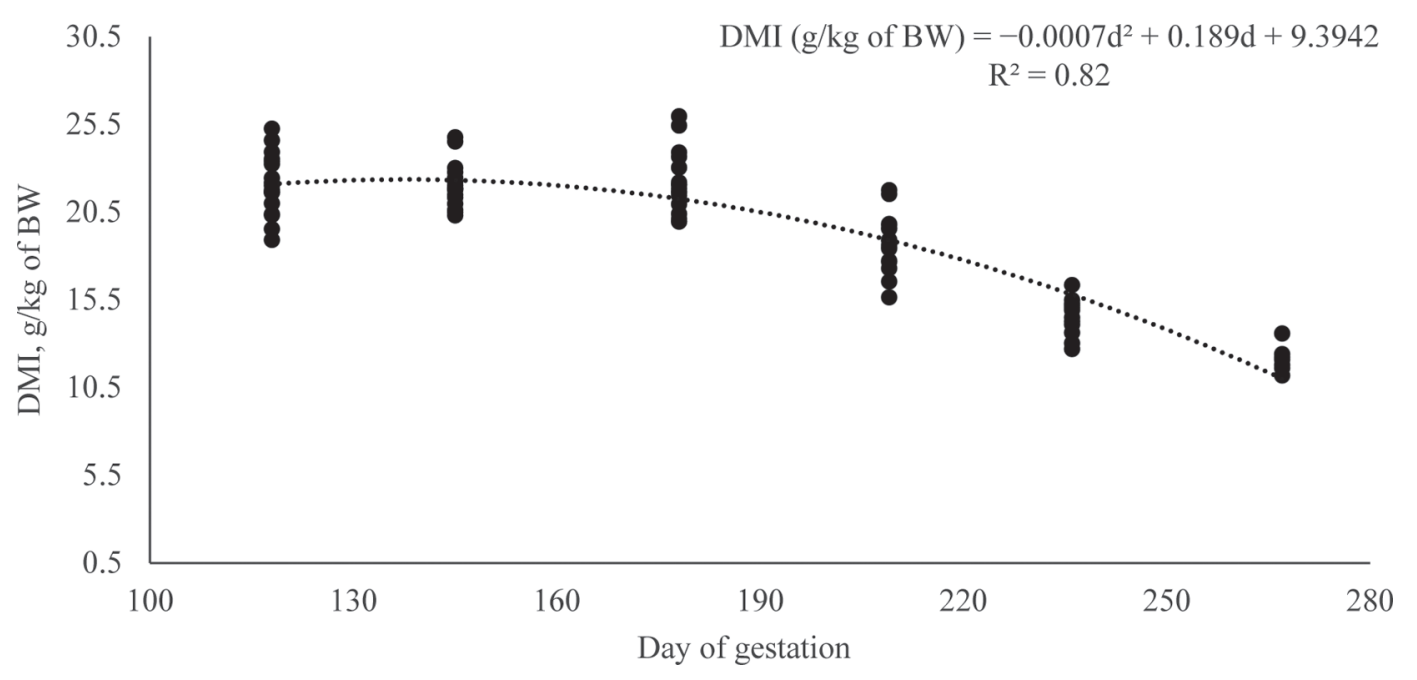

Figure 2. Dry matter intake expressed as grams per kilogram of BW in cows fed ad libitum during gestation and an estimated equation to predict DMI in Holstein $\times$ Gyr pregnant dry cows (118 to $262 \mathrm{~d}$ of gestation). 
BW, and the lowest mass was observed in AL-fed cows at $139 \mathrm{~d}$ of gestation. As expected, KPH expressed as kilogram or grams per kilogram of empty BW was greater $(P<0.01)$ in AL- than in ML-fed cows.

Average daily gain was different $(P<0.01)$ between AL- and ML-fed cows in the 4 DG that were evaluated (Table 5). No difference $(P=0.85)$ was observed for DG in AL- and ML-fed cows. The ADG during gestation of AL-fed cows was $1.11 \pm 0.060 \mathrm{~kg} / \mathrm{d}$, whereas that of ML-fed cows was $0.30 \pm 0.063 \mathrm{~kg} / \mathrm{d}$. Average daily gain in AL-fed cows was about 3.8 times greater than in ML-fed cows. When evaluating ADG without the gravid uterus, differences $(P<0.01)$ were observed between AL- and ML-fed cows, depending on DG. At 139, 199, and $241 \mathrm{~d}$ of gestation, similar $(P=0.54)$ values were observed. The lowest $(P<0.01)$ observed value was at $268 \mathrm{~d}$, but it did not differ $(P=0.78)$ from the values at $241 \mathrm{~d}$ of gestation. Maintenance-fed cows had similar $(P=0.44)$ ADG without the gravid uterus at 139 and $199 \mathrm{~d}$ of gestation. An intermediate $(P=0.02)$ value was observed at $241 \mathrm{~d}$, and the lowest $(P=0.04)$ value was observed at $268 \mathrm{~d}$ of gestation. Empty BW gain was different $(P<0.01)$ between ALand ML-fed cows, but no difference $(P=0.85)$ was observed within FR among DG. The empty BW gain during gestation was $1.27 \pm 0.068 \mathrm{~kg} / \mathrm{d}$ in AL-fed cows and $0.41 \pm 0.058 \mathrm{~kg} / \mathrm{d}$ in ML-fed cows.

\section{DISCUSSION}

\section{Feed Intake}

When comparing the DMI observed at $150 \mathrm{~d}$ and $262 \mathrm{~d}$ of gestation, the decrease in DMI was approximately $40 \%$. Thus, it appears that a diet containing more energy and protein during late gestation should be provided, because this period is the critical time during which energy and protein supplementation support fetal development (Bell, 1995). According to Forbes (1986), the decrease in DMI is associated with a reduction in ruminal volume caused by the rapid increase in fetal size during late gestation; this creates a physical impingement on ruminal volume, because approximately $60 \%$ of fetal growth occurs during the last 2 mo of gestation (Bauman and Currie, 1980). In this study, we observed an approximately $50 \pm 2.6 \%$ increase in fetal BW from d 239 to 268 (Rotta et al., 2015). During the last $70 \mathrm{~d}$ of gestation, we observed that approximately $70 \pm 3.5 \%$ of fetal growth occurred during this period (Rotta et al., 2015). Moreover, concentrations of many hormones in the blood increase or decrease dramatically at parturition and may be potent modifiers of DMI (NRC, 2001). For example, plasma estrogen of placental origin increases in the blood as 

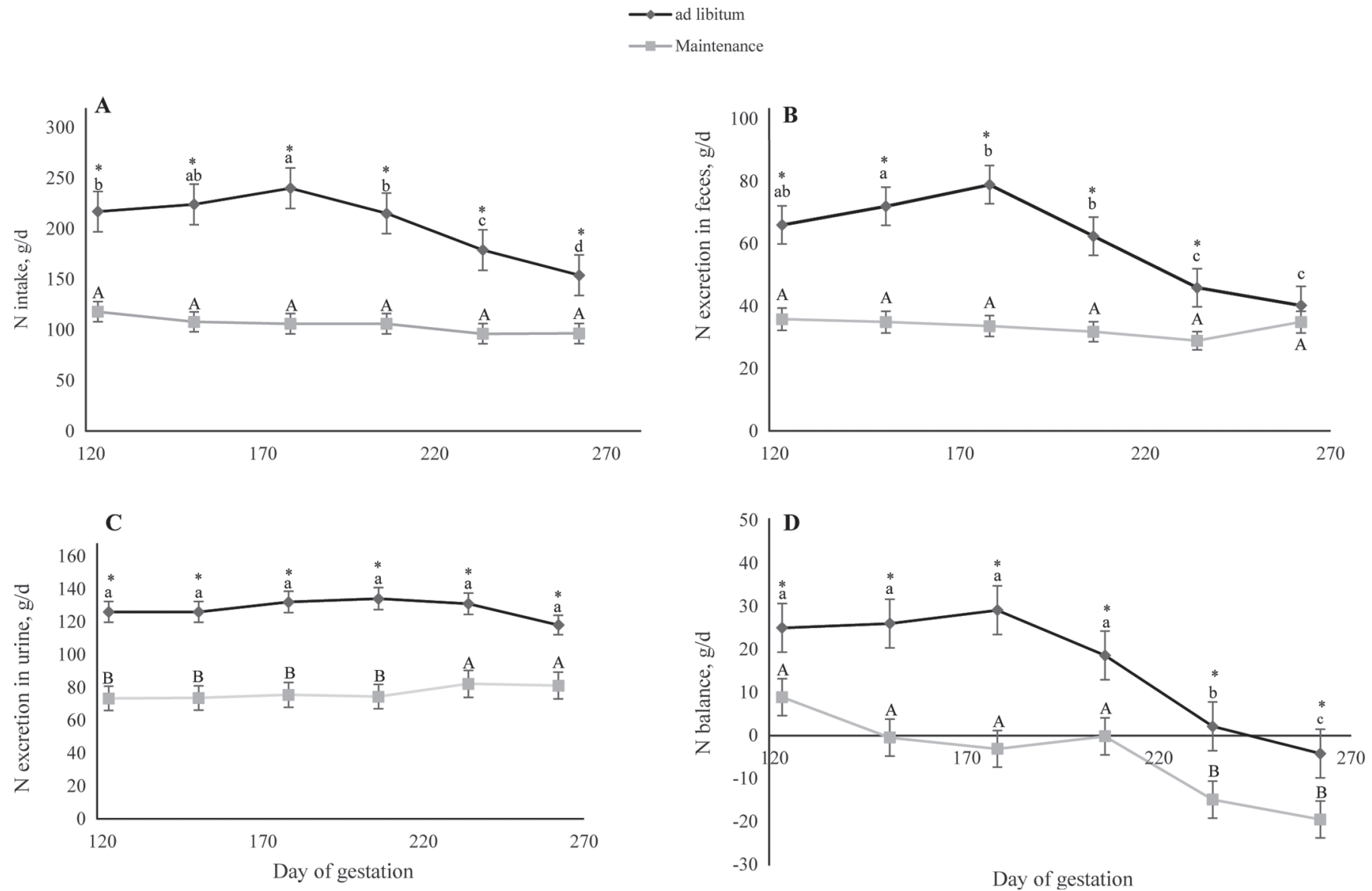

Figure 3. Nitrogen intake (A), $\mathrm{N}$ excretion in feces (B) and urine (C), and $\mathrm{N}$ balance (D) in cows fed ad libitum or maintenance levels during gestation. Results are means $\pm \mathrm{SEM}$. ${ }^{*}$ Different at $P=0.04$ between feeding regimens. Different lowercase letters are different at $P \leq 0.10$ for ad libitum diets; different uppercase letters are different at $P \leq 0.10$ for maintenance diets.

parturition approaches. Exogenous estrogen administration inhibits DMI (Grummer et al., 1995; Eckel, 2004). Reduced DMI during estrus and late pregnancy may reflect greater endogenous estrogen production.

Inert fill in the rumen has also been shown to cause a decrease in feed intake (Dado and Allen, 1995). Moreover, Dado and Allen (1995) observed an increase in the frequency of small meals when high-forage and rumeninert fill were added to the diet. This may therefore explain the decrease in DMI that is often associated with animals on diets with high NDF content. In this study, we used a diet that contained approximately $50 \%$ NDF, which may also be responsible for the decrease in DMI during late gestation. According to Arelovich et al. (2008), diets presenting with $45 \%$ or more NDF are considered high-NDF diets. Forbes (1970) observed that the DMI of ewes changed dramatically during late gestation. This adjustment during pregnancy in ewes has been attributed to changes in ruminal capacity due to the growing fetus and the increased concentra- tion of estrogen (Forbes, 1986). In the present study, we observed that the decreased DMI, expressed as a percentage of BW, began at wk 25 of gestation, which corresponds to $178 \mathrm{~d}$. In agreement with this finding, Ingvartsen and Andersen (2000) reported that Holstein cows decreased DMI from wk 26 of gestation until calving.

\section{Apparent Total-Tract Digestibility}

According to Clark et al. (2007), the level of intake influences apparent total-tract DM digestibility in beef steers, and limit feeding has been shown to increase digestibility of the diet compared with ad libitum feeding (Galyean et al., 1979; Murphy et al., 1994; Clark et al., 2007). However, in the present study, we observed that differences between the 2 FR occurred only from 150 to $206 \mathrm{~d}$ of gestation (Table 3 ).

Independently of the FR that were studied, we observed that apparent total-tract DM digestibility 
Table 4. Effects of different day of gestation and feeding regimens on urinary concentrations of urea and purine derivatives in Holstein $\times$ Gyr cows (means \pm SEM)

\begin{tabular}{|c|c|c|c|c|c|c|c|c|c|c|c|}
\hline \multirow[b]{2}{*}{ Item } & \multicolumn{2}{|c|}{ Feeding regimen } & \multicolumn{6}{|c|}{ Day of gestation } & \multicolumn{3}{|c|}{$P$-value ${ }^{1}$} \\
\hline & Ad libitum & Maintenance & 122 & 150 & 178 & 206 & 234 & 262 & FR & DG & $\mathrm{FR} \times \mathrm{DG}$ \\
\hline Urea, g/d & $205 \pm 4.4$ & $143 \pm 4.2$ & $152 \pm 4.3$ & $161 \pm 4.3$ & $161 \pm 4.3$ & $174 \pm 7.4$ & $186 \pm 8.0$ & $210 \pm 10.7$ & $<0.01$ & $<0.01$ & $<0.01$ \\
\hline Ad libitum & - & - & $187^{\mathrm{a}, \mathrm{A}} \pm 6.2$ & $203^{\mathrm{a}, \mathrm{A}} \pm 6.2$ & $202^{\mathrm{a}, \mathrm{A}} \pm 6.2$ & $215^{\mathrm{a}, \mathrm{A}} \pm 10.7$ & $197^{\mathrm{a}, \mathrm{A}} \pm 11.5$ & $224^{\mathrm{a}, \mathrm{A}} \pm 15.6$ & - & - & - \\
\hline Maintenance & - & - & $117^{\mathrm{b}, \mathrm{B}} \pm 5.9$ & $118^{\mathrm{b}, \mathrm{B}} \pm 5.9$ & $120^{\mathrm{b}, \mathrm{B}} \pm 5.9$ & $132^{\mathrm{b}, \mathrm{B}} \pm 10.3$ & $175^{\mathrm{a}, \mathrm{A}} \pm 11.1$ & $196^{\mathrm{a}, \mathrm{A}} \pm 14.6$ & - & - & - \\
\hline$P$-value & - & - & $<0.01$ & $<0.01$ & $<0.01$ & $<0.01$ & $<0.01$ & $<0.01$ & - & - & - \\
\hline Allantoin, $\mathrm{mmol} / \mathrm{d}$ & $309 \pm 8.8$ & $185 \pm 8.3$ & $259 \pm 8.1$ & $253 \pm 8.1$ & $263 \pm 8.1$ & $249 \pm 13.4$ & $233 \pm 16.0$ & $228 \pm 23.2$ & $<0.01$ & 0.54 & 0.81 \\
\hline Uric acid. $\mathrm{mmol} / \mathrm{d}$ & $36.3 \pm 1.60$ & $13.1 \pm 1.49$ & $22.2^{\mathrm{b}} \pm 1.46$ & $18.4^{\mathrm{b}} \pm 1.46$ & $25.0^{\mathrm{ab}} \pm 1.46$ & $24.9^{\mathrm{ab}} \pm 2.43$ & $29.3^{\mathrm{a}} \pm 2.89$ & $30.5^{\mathrm{a}} \pm 4.20$ & $<0.01$ & 0.02 & 0.54 \\
\hline $\mathrm{AP}^{2}{ }^{\mathrm{mmol} / \mathrm{d}}$ & $302 \pm 9.0$ & $158 \pm 8.4$ & $241 \pm 8.2$ & $228 \pm 8.2$ & $247 \pm 8.2$ & $229 \pm 13.7$ & $218 \pm 16.2$ & $219 \pm 19.7$ & $<0.01$ & 0.61 & 0.79 \\
\hline Microbial $^{3}$ & $182 \pm 5.6$ & $103 \pm 5.3$ & $158 \pm 5.2$ & $153 \pm 5.2$ & $161 \pm 5.2$ & $144 \pm 8.6$ & $122 \pm 10.2$ & $138 \pm 14.8$ & - & - & - \\
\hline Microbial efficiency ${ }^{4}$ & $134 \pm 4.2$ & $141 \pm 3.9$ & $132 \pm 3.9$ & $134 \pm 3.9$ & $139 \pm 3.9$ & $136 \pm 6.4$ & $142 \pm 7.6$ & $143 \pm 11.0$ & 0.18 & 0.79 & 0.84 \\
\hline
\end{tabular}

${ }_{\mathrm{a}, \mathrm{b}}$ Means within a row with different superscripts differ $(P \leq 0.10)$.

A,B Means within a column with different superscripts differ $(P \leq 0.10)$

${ }^{1} \mathrm{FR}=$ feeding regimen; $\mathrm{DG}=$ day of gestation; $\mathrm{FR} \times \mathrm{DG}=$ interaction between feeding regimen and day of gestation.

${ }^{2}$ Absorbed purines.

${ }^{3}$ Determined by assuming daily purine derivative $(\mathrm{PD})$ excretion $\left(\mathrm{dPD} ; \mathrm{mmol} / \mathrm{kg}\right.$ of $\left.\mathrm{BW}^{0.75}\right)=\mathrm{PD}$ index $\times 0.9 ;$ daily absorbed purines $($ daP $)=\left[\mathrm{dPD}\left(\mathrm{mmol} / \mathrm{kg}\right.\right.$ of $\left.\mathrm{BW} \mathrm{W}^{0.75}\right)-0.385$

$\left.\times \mathrm{BW}^{0.75}\right]+0.85$; and microbial $\mathrm{N}(\mathrm{g}$ of $\mathrm{N} / \mathrm{d})=(\mathrm{daP} \times 70) /(0.116 \times 0.83 \times 1,000)$.

${ }^{4}$ Expressed as g of $\mathrm{CP} / \mathrm{kg}$ of $\mathrm{TDN}$.

Table 5. Effects of different day of gestation and feeding regimens on carcass characteristics of Holstein $\times$ Gyr cows (means \pm SEM)

\begin{tabular}{|c|c|c|c|c|c|c|c|c|c|}
\hline \multirow[b]{2}{*}{ Item } & \multicolumn{2}{|c|}{ Feeding regimen } & \multicolumn{4}{|c|}{ Day of gestation } & \multicolumn{3}{|c|}{$P$-value ${ }^{1}$} \\
\hline & Ad libitum & Maintenance & 139 & 199 & 241 & 268 & FR & DG & $\mathrm{FR} \times \mathrm{DG}$ \\
\hline No. & 20 & 23 & 10 & 11 & 11 & 11 & & & \\
\hline Initial BW, kg & $482 \pm 10.6$ & $477 \pm 9.6$ & $488 \pm 14.2$ & $480 \pm 13.9$ & $480 \pm 13.9$ & $468 \pm 13.9$ & - & - & - \\
\hline Final BW, $\mathrm{kg}$ & $644 \pm 12.9$ & $521 \pm 11.7$ & $553 \pm 17.2$ & $577 \pm 16.9$ & $596 \pm 16.9$ & $603 \pm 16.9$ & $<0.01$ & 0.21 & 0.64 \\
\hline Empty BW, kg & $580 \pm 11.0$ & $456 \pm 10.0$ & $484^{\mathrm{b}} \pm 14.7$ & $505^{\mathrm{b}} \pm 14.4$ & $537^{\mathrm{a}} \pm 14.4$ & $545^{\mathrm{a}} \pm 14.4$ & $<0.01$ & 0.02 & 0.51 \\
\hline $\mathrm{ADG}, \mathrm{kg}$ & $1.11 \pm 0.06$ & $0.30 \pm 0.05$ & $0.73 \pm 0.09$ & $0.73 \pm 0.08$ & $0.70 \pm 0.08$ & $0.68 \pm 0.08$ & $<0.01$ & 0.85 & 0.65 \\
\hline ADG without gravid uterus, $\mathrm{kg}$ & $0.94 \pm 0.05$ & $0.11 \pm 0.04$ & $0.61 \pm 0.07$ & $0.61 \pm 0.06$ & $0.48 \pm 0.06$ & $0.41 \pm 0.06$ & $<0.01$ & 0.04 & 0.02 \\
\hline Ad libitum & - & - & $1.05^{\mathrm{a}, \mathrm{A}} \pm 0.11$ & $1.00^{\mathrm{a}, \mathrm{A}} \pm 0.10$ & $0.90^{\mathrm{ab}, \mathrm{A}} \pm 0.10$ & $0.82^{\mathrm{b}, \mathrm{A}} \pm 0.10$ & - & - & - \\
\hline Maintenance & - & - & $0.17^{\mathrm{a}, \mathrm{B}} \pm 0.06$ & $0.22^{\mathrm{a}, \mathrm{B}} \pm 0.05$ & $0.05^{\mathrm{b}, \mathrm{B}} \pm 0.05$ & $-0.01^{\mathrm{c}, \mathrm{B}} \pm 0.05$ & - & - & - \\
\hline$P$-value & - & - & $<0.01$ & $<0.01$ & $<0.01$ & $<0.01$ & - & - & - \\
\hline Empty BW gain, kg & $1.27 \pm 0.07$ & $0.41 \pm 0.06$ & $0.82 \pm 0.09$ & $0.88 \pm 0.10$ & $0.84 \pm 0.10$ & $0.82 \pm 0.10$ & $<0.01$ & 0.85 & 0.87 \\
\hline Gastrointestinal content, $\mathrm{kg}$ & $64.1 \pm 0.59$ & $65.3 \pm 0.52$ & $69.0^{\mathrm{a}} \pm 0.84$ & $72.2^{\mathrm{a}} \pm 0.78$ & $58.9^{\mathrm{b}} \pm 0.78$ & $57.8^{\mathrm{b}} \pm 0.78$ & 0.21 & 0.01 & 0.63 \\
\hline Hot carcass dressing, $\%$ & $52.2 \pm 0.48$ & $51.5 \pm 0.44$ & $54.2^{\mathrm{a}} \pm 0.67$ & $52.5^{\mathrm{a}} \pm 0.63$ & $52.0^{\mathrm{a}} \pm 0.63$ & $48.8^{\mathrm{b}} \pm 0.63$ & 0.27 & $<0.01$ & 0.42 \\
\hline Cold carcass dressing, $\%$ & $51.6 \pm 0.46$ & $50.4 \pm 0.41$ & $52.9^{\mathrm{a}} \pm 0.64$ & $51.8^{\mathrm{a}} \pm 0.60$ & $51.0^{\mathrm{a}} \pm 0.60$ & $48.1^{\mathrm{b}} \pm 0.60$ & 0.16 & $<0.01$ & 0.42 \\
\hline
\end{tabular}

$œ \quad{ }^{\mathrm{a}-\mathrm{c}}$ Means within a row with different superscripts differ $(P \leq 0.10)$.

$\underset{\mathrm{A}, \mathrm{B}}{\mathrm{B}}$ Means within a column with different superscripts differ $(P \leq 0.10)$

or $\quad{ }^{1} \mathrm{FR}=$ feeding regimen; $\mathrm{DG}=$ day of gestation; $\mathrm{FR} \times \mathrm{DG}=$ interaction between feeding regimen and day of gestation 



Figure 4. Kidney, pelvic, and heart fat (KPH, $\mathrm{kg} ; \mathrm{A}) ; \mathrm{KPH}(\mathrm{g} / \mathrm{kg}$ of empty BW; B); mesentery mass (kg; C); mesentery mass (g/kg of empty BW; D); and rib fat thickness $(\mathrm{mm}$; E) in cows fed ad libitum $(\bullet)$ or maintenance $(\mathrm{O})$ levels during gestation. Results are means \pm SEM. Different lowercase letters differed among day of gestation; different uppercase letters differed between feeding regimens at $P \leq 0.10$.

decreased with advancing gestation. Beharka et al. (1988), Faichney and White (1988), and Scheaffer et al. (2001) also observed decreases in apparent total-tract DM digestibility in ewes, beef cows, and beef heifers, respectively. Beharka et al. (1988) observed that apparent total-tract DM digestibility decreased while the rate of passage increased. According to those authors, because the rate of passage and digestibility are competing forces, the decreased apparent total-tract DM digestibility may be explained in part by the increased passage rate. Okine and Mathison (1991) suggested that the passage rate of NDF increased with increasing DMI. Cows fed ad libitum are therefore supposed to have a greater passage rate of NDF than ML-fed cows, which likely explains the reduction in total-tract apparent digestibility of NDF.

\section{Nitrogen Balance}

There has been great interest in investigating the potential of specific on-farm alternatives to reduce $\mathrm{N}$ losses (Spek et al., 2013). Previous studies have shown that the excretion of $\mathrm{N}$ in urine is linearly related to $\mathrm{N}$ intake in beef (Hoekstra et al., 2007) and lactating dairy cows (Tas et al., 2006; Higgs et al., 2012). Nevertheless, in pregnant AL-fed cows, it seems that N excretion in urine does not exhibit the same response (Figure 3). Despite the lower values of $\mathrm{N}$ intake at 234 
and $262 \mathrm{~d}$ of gestation, the excretion of $\mathrm{N}$ in urine did not change. This may be due to lower energy balance during the last phase of gestation (Bauman and Currie, 1980). The urea excretion in urine (Table 4) was also similar among the different DG in AL-fed cows, again showing that although $\mathrm{N}$ intake was less, $\mathrm{N}$ excretion in urine did not change.

Nitrogen excretion in urine was greater at 234 and $262 \mathrm{~d}$ of gestation in ML-fed cows, although $\mathrm{N}$ intake was similar among the different DG, and this may be related to AA catabolism (Bauman and Currie, 1980). Moreover, Kwon et al. (2004) demonstrated that maternal malnutrition reduces concentrations of $\mathrm{AA}$ in ovine maternal and fetal plasma as well as in fetal fluids. Because d 234 is considered to be in the final third of gestation, the net requirements are greater (Bell, 1995). Maintenance-fed diets should provide sufficient energy and AA content for fetal development. Thus, greater AA catabolism may be responsible for increasing $\mathrm{N}$ excretion in urine. The main indicator of this increased catabolism is that the greatest urea excretion concentration occurred at 234 and $262 \mathrm{~d}$ of gestation in MLfed cows. Under prolonged fasting conditions in dairy cows, AA catabolism by the conceptus may increase to provide approximately $70 \%$ of the fetal glucose (Bell, 1995). Thus, despite the fact that ML-fed cows may not have enough $\mathrm{N}$ to meet their requirements, the greater $\mathrm{N}$ excretion in urine cannot be avoided because part of the $\mathrm{N}$ comes from AA catabolism.

The negative $\mathrm{N}$ balance value at $262 \mathrm{~d}$ of gestation can be explained by the lowest $\mathrm{N}$ intake at that time, and because the conceptus (fetus, placenta, associated fetal membranes, and supporting uterine tissues) makes extensive, direct demands upon maternal supplies of glucose and AA during late pregnancy (Ferrell, 1991). During late gestation, 35 to $40 \%$ of fetal energy is supplied by glucose and the fetal-placental metabolite lactate, whereas an additional $55 \%$ is supplied by AA (Comline and Silver, 1976; Reynolds et al., 1986; Ferrell, 1991). Thus, AA catabolism may result in increased urea excretion and explain the increased $\mathrm{N}$ excretion in urine, and thus, contribute to a lower value for $\mathrm{N}$ balance.

Maintenance-fed cows had lower values for $\mathrm{N}$ balance in all DG that were studied compared with AL-fed cows; moreover, the $\mathrm{N}$ balance was slightly negative from 150 to $206 \mathrm{~d}$ of gestation in ML-fed cows, at approximately $-1.30 \mathrm{~g} / \mathrm{d}$ of $\mathrm{N}$. However, at d 234 and 262 of gestation, an increase in the negative values of $\mathrm{N}$ balance was observed, to approximately $-17.0 \mathrm{~g} / \mathrm{d}$ of $\mathrm{N}$. Thus, the last 2 mo evaluated in this study demonstrated a greater negative magnitude of $\mathrm{N}$ balance in ML-fed cows. In the last DG that was evaluated in this study, a negative value was observed for ADG without the gravid uterus.
The FR that decreases the amount of excreted $\mathrm{N}$ may be considered a good alternative to limit the environmental impact of $\mathrm{N}$ produced by the dairy industry. According to Spears et al. (2003), the dairy industry has been identified as a potential contributor to point and nonpoint source environmental pollution. Van Egmond et al. (2002) reported that the main sources of reactive $\mathrm{N}$ in the environment are fertilizers and manure. The $\mathrm{N}$ in urine is rapidly converted into ammonia by urease in the environment (Tamminga, 1992).

\section{Excretion of Purine Derivatives}

According to Barbosa et al. (2011), allantoin and uric acid in urine are linearly related to DMI, which is supported by the findings of the present study. Johnson et al. (2003) suggested that diet is one of the main factors that contribute to greater values of uric acid excretion in urine. Ad libitum-fed cows had about a $90 \%$ greater microbial $\mathrm{N}$ than ML-fed cows. According to Clark and Davis (1983), the deficiency of digestible OM and protein may decrease microbial $\mathrm{N}$ synthesis in the rumen. The amount of consumed feed is the nutritional factor that limits performance when balanced diets are fed to dairy cows, and microbial $\mathrm{N}$ content increases when cows consume increasing amounts of the same diet (Clark et al., 2007). Those authors demonstrated that microbial $\mathrm{N}$ is linearly related to OM intake. Thus, the greater OM intake observed in AL-fed cows may explain the greater microbial $\mathrm{N}$ synthesis for AL- than for ML-fed cows. The microbial efficiency values in this study were close $(137 \pm 2.1 \mathrm{~g}$ of $\mathrm{CP} / \mathrm{kg}$ of $\mathrm{TDN})$ to those suggested by the NRC $(2001 ; 130 \mathrm{~g}$ of $\mathrm{CP} / \mathrm{kg}$ of TDN).

\section{Carcass Characteristics, Fat Deposition, and Performance}

The greater values for hot carcass and cold carcass dressings that were observed at 139, 199, and $241 \mathrm{~d}$ versus $268 \mathrm{~d}$ of gestation may be related to gravid uterine growth (fetus, uterus, placenta, and liquids). At $268 \mathrm{~d}$ of gestation, the gravid uterus was approximately 500, 170 , and $60 \%$ heavier than at 139, 199, and $241 \mathrm{~d}$ of gestation, respectively (Rotta et al., 2015). Thus, we can infer that rumen capacity was greater at 139 and $199 \mathrm{~d}$ of gestation than at 241 and $268 \mathrm{~d}$. The greater rumen capacity is likely due to the presence of increased digesta and growth of the fetus during these DG.

Cows that were fed AL gained body fat during gestation and had an increased rib fat thickness, whereas ML-fed cows had a constant amount of body fat and rib fat thickness. Differences in the mass of viscera and internal fat have been reported in heifers fed with dif- 
ferent levels of energy (Lage et al., 2012). This also occurred in our study because AL-fed cows typically had heavier mass of viscera and internal fat (Rotta et al., 2015) compared with ML-fed cows. These differences may contribute to differences in empty BW and, concomitantly, the similarity of cold carcass dressings between FR. Nutritional management is one of the main factors that can affect fat deposition. Cattle that are fed ML must prioritize energy utilization to maintain vital functions and internal organs of the body such as the liver, kidneys, heart, and gastrointestinal tract. These animals utilize about $40 \%$ of the energy requirement for maintenance (Koong et al., 1985). Maintenance-fed cows have less available energy for rib fat thickness deposition than AL-fed cows.

As expected, the increased mass of mesentery observed in AL-fed cows was likely the result of increased caloric intake. Thus, part of the excess energy in the diet of pregnant AL-fed cows was converted to mesentery, which is related to increased energy requirements. A persistent positive energy balance leads to deposition of fat in the animal (Davis Rincker et al., 2008). Fat deposition can be chemically characterized by a continued accumulation of lipids, primarily in the form of triacylglycerides, and morphologically characterized by hyperplasia and hypertrophy (Nürnberg et al., 1998). In the present study, cows were approximately 5 yr old, and consequently, fat deposition may have occurred for the most part due to hypertrophy (Okumura et al., 2007).

\section{CONCLUSIONS}

We conclude that DMI expressed as a percentage of BW decreased as gestation progressed in Holstein $x$ Gyr cows. Cows fed at $1.15 \%$ of BW with a diet containing $93 \%$ roughage had greater DM and OM apparent total-tract digestibility than AL-fed cows between 150 to $206 \mathrm{~d}$ of gestation; however, DM apparent total-tract digestibility was reduced in late-gestation. Urinary $\mathrm{N}$ excretion in pregnant cows that are fed AL was not related to $\mathrm{N}$ intake. Cows that are fed at $1.15 \%$ of $\mathrm{BW}$ may affect the environment less because they have less $\mathrm{N}$ excretion in feces and urine. Part of the excess energy from the AL diet was stored as mesenteric or KPH fat. During the last month of gestation, AL seems to be the most appropriate FR to avoid loss of BW.

\section{REFERENCES}

AOAC International. 2000. Official Methods of Analysis. 17th ed. AOAC International, Arlington, VA.

AOAC International. 2006. Official Methods of Analysis. 18th ed. AOAC International, Gaithersburg, MD.
Arelovich, H. M., C. S. Abney, J. A. Vizcarra, and M. L. Galyean. 2008. Effects of dietary neutral detergent fiber on intakes of dry matter and net energy by dairy and beef cattle: analysis of published data. Prof. Anim. Sci. 24:375-383.

Barbosa, A. M., R. F. D. Valadares, S. C. Valadares Filho, D. S. Pina, E. Detmann, and M. I. Leao. 2011. Endogenous fraction and urinary recovery of purine derivatives obtained by different methods in Nellore cattle. J. Anim. Sci. 89:510-519.

Bauman, D. E., and W. B. Currie. 1980. Partitioning of nutrients during pregnancy and lactation: A review of mechanisms involving homeostasis and homeorhesis. J. Dairy Sci. 63:1514-1529. http:/ dx.doi.org/10.3168/jds.S0022-0302(80)83111-0.

Beharka, A., B. Cochran, D. Harmon, and T. Avery. 1988. The influence of stage of pregnancy on digestion characteristics of beef cows. Kansas State Univ. Prog. Rep. 539:13-15.

Bell, A. W. 1995. Regulation of organic nutrient metabolism during transition from late pregnancy to early lactation. J. Anim. Sci. 73:2804-2819.

Brasil. 1997. Regulamento da Inspeção Industrial e Sanitária de Produtos de Origem Animal [Food of animal origin sanitary and industry inspection]. Ministério da Agricultura, Pecuária e Abastecimento, Brasilia, Brazil.

Chen, X. B. 1989. Excretion of purine derivatives by sheep and cattle and its use for the estimation of absorbed microbial protein. PhD Thesis. University of Aberdeen, Aberdeen, UK.

Chen, X. B., P. Susmel, B. Stefanon, and E. R. Orskov. 1995. Protein metabolism and nutrition. Pages 325-329 in Proc. 7th Int. Symp. Protein Metab. Nutr. EAAP Scientific Series, Vale de Santarém, Portugal.

Clark, J. H., and C. L. Davis. 1983. Future improvement of milk production: Potential for nutritional improvement. J. Anim. Sci. $57: 750-764$

Clark, J. H., K. C. Olson, T. B. Schmidt, M. L. Linville, D. O. Alkire, D. L. Meyer, G. K. Rentfrow, C. C. Carr, and E. P. Berg. 2007. Effects of dry matter intake restriction on diet digestion, energy partitioning, nutrient retention, and ruminal fermentation by beef steers. J. Anim. Sci. 85:3383-3390. http://dx.doi.org/10.2527/ jas.2006-741.

Comline, R. S., and M. Silver. 1976. Some aspects of foetal and uteroplacental metabolism in cows with indwelling umbilical and uterine vascular catheters. J. Physiol. 260:571-586.

Czauderna, M., and J. Kowalczyk. 2000. Quantification of allantoin, uric acid, xanthine and hypoxanthine in ovine urine by high-performance liquid chromatography and photodiode array detection. J. Chromatogr. B Biomed. Sci. Appl. 744:129-138.

Dado, R. G., and M. S. Allen. 1995. Intake limitations, feeding behavior, and rumen function of cows challenged with rumen fill from dietary fiber or inert bulk. J. Dairy Sci. 78:118-133. http:// dx.doi.org/10.3168/jds.S0022-0302(95)76622-X.

Davis Rincker, L. E., M. S. W. Nielsen, L. T. Chapin, J. S. Liesman, and M. J. VandeHaar. 2008. Effects of feeding prepubertal heifers a high-energy diet for three, six, or twelve weeks on feed intake, body growth, and fat deposition. J. Dairy Sci. 91:1913-1925. http://dx.doi.org/10.3168/jds.2006-210.

Detmann, E., and S. C. Valadares Filho. 2010. On the estimation of non-fibrous carbohydrates in feeds and diets. Braz. J. Vet. Anim. Sci. 62:980-984. http://dx.doi.org/10.1590/S010209352010000400030 .

Dorshorst, M. E., and R. R. Grummer. 2002. Effects of day relative to parturition and dietary crude protein on rumen fermentation in prepartum transition cows. J. Dairy Sci. 85:2290-2298. http:// dx.doi.org/10.3168/jds.S0022-0302(02)74309-9.

Duarte, M. S., M. P. Giombelli, P. V. R. Paulino, N. V. L. Serao, T. S. Martins, P. I. S. Totaro, C. A. Neves, S. C. Valadares Filho, M. V. Dodson, M. Zhu, and M. Du. 2013. Effects of maternal nutrition development of gastrointestinal tract of bovine fetus at different stages of gestation. Livest. Sci. 153:60-65. http://dx.doi. org/10.1016/j.livsci.2013.01.006.

Eckel, L. A. 2004. Estradiol: A rhythmic, inhibitory, indirect control of meal size. Physiol. Behav. 82:35-41. http://dx.doi.org/10.1016/j. physbeh.2004.04.023. 
Eriksson, T., M. Murphy, P. Ciszuk, and E. Burstedt. 2004. Nitrogen balance, microbial protein production, and milk production in dairy cows fed fodder beets and potatoes, or barley. J. Dairy Sci. 87:1057-1070. http://dx.doi.org/10.3168/jds.S00220302(04)73252-X.

Faichney, G. A., and G. A. White. 1988. Partition of organic matter, fibre and protein digestion in ewes fed at a constant rate throughout gestation. Aust. J. Agric. Res. 39:493-504.

Ferrell, C. L. 1991. Maternal and fetal influences on uterine and conceptus development in the cow: II. Blood flow and nutrient flux. J. Anim. Sci. 69:1954-1965.

Forbes, J. M. 1970. Voluntary food intake of pregnant ewes. J. Anim. Sci. 31:1222-1227.

Forbes, J. M. 1986. The effects of sex hormones, pregnancy, and lactation on digestion, metabolism, and voluntary food intake. Pages 420-435 in Control of Digestion and Metabolism in Ruminants. L. P. Milligan, W. L. Grovum and A. Dobson, ed. Prentice-Hall, Englewood Cliffs, NJ.

French, P. D. 2006. Dry matter intake and blood parameters of nonlactating Holstein and Jersey cows in late gestation. J. Dairy Sci. 89:1057-1061. http://dx.doi.org/10.3168/jds.S00220302(06)72173-7.

Galyean, M. L., D. G. Wagner, and F. N. Owens. 1979. Level of feed intake and site and extent of digestion of high concentrate diets by steers. J. Anim. Sci. 49:199-203.

George, S. K., M. T. Dipu, U. R. Mehra, P. Singh, A. K. Verma, and J. S. Rangaokar. 2006. Improved HPLC method for the simultaneous determination of allantoin, uric acid and creatinine in cattle urine. J. Chromatogr. B Analyt. Technol. Biomed. Life Sci. 832:134-137. http://dx.doi.org/10.1016/j.jchromb.2005.10.051.

Greiner, S. P., G. H. Rouse, D. E. Wilson, L. V. Cundiff, and T. L. Wheeler. 2003. The relationship between ultrasound measurements and carcass fat thickness and longissimus muscle area in beef cattle. J. Anim. Sci. 81:676-682. http://dx.doi.org/10.1016/j. meatsci.2013.01.008.

Grummer, R. R., P. C. Hoffman, M. L. Luck, and J. Bertics. 1995. Effect of prepartum and postpartum dietary energy on growth and lactation of primiparous cows. J. Dairy Sci. 78:172-180. http:// dx.doi.org/10.3168/jds.S0022-0302(95)76627-9.

Hayirli, A., and R. R. Grummer. 2004. Factors affecting dry matter intake prepartum in relationship to etiology of peripartum lipid-related metabolic disorders: A review. Can. J. Anim. Sci. 84:337-347.

Hayirli, A., R. R. Grummer, E. V. Nordheim, and P. M. Crump. 2002. Animal and dietary factors affecting feed intake during the prefresh transition period in Holsteins. J. Dairy Sci. 85:3430-3443. http://dx.doi.org/10.3168/jds.S0022-0302(02)74431-7.

Hayirli, A., R. R. Grummer, E. V. Nordheim, and P. M. Crump. 2003. Models for predicting dry matter intake of Holsteins during the prefresh transition period . J. Dairy Sci. 86:1771-1779. http:// dx.doi.org/10.3168/jds.S0022-0302(03)73762-X.

Herd, R. M., J. A. Archer, and M. E. van Amburgh. 2003. Reducing the cost of beef cattle production through genetic improvement in residual feed intake: Opportunity and challenges to application. J. Anim. Sci. 81:E9-E17.

Higgs, R. J., L. E. Chase, and M. E. van Amburgh. 2012. Development and evaluation of equations in the Cornell Net Carbohydrate and Protein System to predict nitrogen excretion in lactating dairy cows. J. Dairy Sci. 95:2004-2014. http://dx.doi.org/10.3168/ jds.2011-4810.

Hoekstra, N. J., R. P. O. Schulte, P. C. Struik, and E. A. Lantinga. 2007. Pathways to improving the $\mathrm{N}$ efficiency of grazing bovines. Eur. J. Agron. 26:363-374. http://dx.doi.org/10.1016/j. eja.2006.12.002.

IBGE. 2009. Censo Agropecuario. Accessed Dec. 8, 2014. http://www. ibge.gov.br/home/estatistica/economia/agropecuaria/censoagro/.

Ingvartsen, K. L., and J. B. Andersen. 2000. Integration of metabolism and intake regulation: A 511 review focusing on periparturient animals. J. Dairy Sci. 83:1573-1597. http://dx.doi.org/10.3168/ jds.S0022-0302(00)75029-6.
Johnson, R. J., D. Kang, D. Feig, S. Kivlighn, J. Kanellis, S. Watanabe, K. R. Tuttle, B. Rodriguez-Iturbe, J. Herrera-Acosta, and M. Mazzali. 2003. Is there a pathogenetic role for uric acid in hypertension and cardiovascular and renal disease? Hypertension 41:11831190. http://dx.doi.org/10.1161/01.HYP.0000069700.62727.C5.

Koong, L. J., C. L. Ferrell, and J. A. Nienaber. 1985. Assessment of interrelationships among levels of intake and production, organ size and fasting heat production in growing animals. J. Nutr. 115:1383-1390.

Kwon, H., S. P. Ford, F. W. Bazer, T. E. Spencer, P. W. Nathanielsz, M. J. Nijland, B. W. Hess, and G. Wu. 2004. Maternal nutrient restriction reduces concentrations of amino acids and polyamines in ovine maternal and fetal fluids. Biol. Reprod. 71:901-908. http:// dx.doi.org/10.1095/biolreprod.104.029645.

Lage, J. F., P. V. R. Paulino, S. C. Valadares Filho, E. J. O. Souza, M. S. Duarte, P. B. Benedeti, N. K. P. Souza, and R. B. Cox. 2012. Influence of genetic type and level of concentrate in the finishing diet on carcass and meat quality traits in beef heifers. Meat Sci. 90:770-774. http://dx.doi.org/10.1016/j.meatsci.2011.11.012.

Lippke, H., W. C. Ellis, and B. F. Jacobs. 1986. Recovery of indigestible fiber from feces of sheep and cattle on forage diets. J. Anim. Sci. 69:403-412.

Mellado, M., F. Coronel, A. Estrada, and F. G. Rios. 2011. Lactation performance of Holstein and Holstein x Gyr cattle under intensive condition in a subtropical environment. Trop. Subtrop. Agroecosyt. $14: 927-931$.

Mertens, D. R., M. Allen, J. Carmany, J. Clegg, A. Davidowicz, M. Drouches, K. Frank, D. Gambin, M. Garkie, B. Gildemeister, D. Jeffress, C. S. Jeon, D. Jones, D. Kaplan, G. N. Kim, S. Kobata, D. Main, X. Moua, B. Paul, J. Robertson, D. Tayson, N. Thiex, J. Williams, and M. Wolf. 2002. Gravimetric determination of amylase-treated neutral detergent fiber in feeds with refluxing in beakers or crucibles: Collaborative study. J. AOAC Int. $85: 1217-1240$.

Murphy, T. A., S. C. Loerch, and F. E. Smith. 1994. Effects of feeding high-concentrate diets at restricted intakes on digestibility and nitrogen metabolism in growing lambs. J. Anim. Sci. 72:1583-1590.

NRC. 2001. Nutrient Requirements of Dairy Cattle. 7th rev. ed. Natl. Acad. Press, Washington, DC.

Nennich, T. D., J. H. Harrison, L. M. van Wieringen, N. R. St-Pierre, R. L. Kincaid, M. A. Wattiaux, D. L. Davidson, and E. Block. 2006. Prediction and evaluation of urine and urinary nitrogen and mineral excretion from dairy cattle. J. Dairy Sci. 89:353-364. http://dx.doi.org/10.3168/jds.S0022-0302(06)72101-4.

Nürnberg, K., J. Wegner, and K. Ender. 1998. Factors influencing fat composition in muscle and adipose tissue of farm animals. Livest. Prod. Sci. 56:145-156. http://dx.doi.org/10.1016/S03016226(98)00188-2.

Okine, E. K., and G. W. Mathison. 1991. Effects of feed intake on particle distribution, passage of digesta, and extent of digestion in the gastrointestinal tract of cattle. J. Anim. Sci. 69:3435-3445.

Okumura, T., K. Saito, H. Sakuma, T. Nade, S. Nakayama, K. Fujita, and T. Kawamura. 2007. Intramuscular fat deposition in principal muscles from twenty-four to thirty months of age using identical twins of Japanese Black steers. J. Anim. Sci. 85:1902-1907. http://dx.doi.org/10.2527/jas.2006-752.

Pacheco, D., K. Lowe, J. L. Burke, and G. P. Cosgrove. 2009. Urinary nitrogen excretion from cows at different stage of lactation grazing different ryegrass cultivars during spring or autumn. Proc. N.Z. Soc. Anim. Prod. 69:196-200.

Reynolds, L. P., C. L. Ferrell, D. A. Robertson, and S. P. Ford. 1986 Metabolism of the gravid uterus, foetus and utero-placenta at several stages of gestation in cows. J. Agric. Sci. 106:437-444. http://dx.doi.org/10.1017/S0021859600063309.

Rotta, P. P., S. C. Valadares Filho, T. R. Santos, L. F. Costa e Silva, T. E. Engle, M. I. Marcondes, M. M. Campos, A. C. B. Menezes, and A. A. Lobo. 2015. Effects of stage of gestation and feeding regimen in Holstein $\times$ Gyr cows: II. Maternal and fetal visceral organ mass. J. Dairy Sci. 98:3211-3223. 10.3168/jds.2014-8282.

Santana, M. L., R. J. Pereira, A. B. Bignardi, L. El Faro, H. Tonhati, and L. G. Albequerque. 2014. History, structure, and genetic diver- 
sity of Brazilian Gir cattle. Livest. Sci. 163:26-33. http://dx.doi. org/10.1016/j.livsci.2014.02.007.

Scheaffer, A. N., J. S. Caton, M. L. Bauer, and L. P. Reynolds. 2001. Influence of pregnancy on body weight, ruminal characteristics, and visceral organ mass in beef heifers. J. Anim. Sci. 79:24812490.

Silva, A. A., A. L. S. Azevedo, R. S. Verneque, K. Gasparini, M. G. C. D. Peixoto, M. V. G. B. Silva, P. S. Lopes, S. E. F. Guimaraes, and M. A. Machado. 2011. Quantitative trait loci affecting milk production traits on bovine chromosome 6 in zebuine Gyr breed. J. Dairy Sci. 94:971-980. http://dx.doi.org/10.3168/jds.2009-2970.

Spears, R. A., R. A. Kohn, and A. J. Young. 2003. Whole-farm nitrogen balance on western dairy farms. J. Dairy Sci. 86:4178-4186. http://dx.doi.org/10.3168/jds.S0022-0302(03)74033-8.

Spek, J. W., J. Dijkstra, G. van Duinkerken, W. H. Hendriks, and A. Bannink. 2013. Prediction of urinary nitrogen and urinary nitrogen excretion by lactating dairy cattle in northwestern Europe and North America: A meta-analysis. J. Dairy Sci. 96:4310-4322. http://dx.doi.org/10.3168/jds.2012-6265.

Tamminga, S. 1992. Nutrition management of dairy cows as a contribution to pollution control. J. Dairy Sci. 75:345-357. http:// dx.doi.org/10.3168/jds.S0022-0302(92)77770-4.
Tas, B. M., H. Z. Taweel, H. J. Smit, A. Elgersma, J. Dijkstra and S. Tamminga. 2006. Effects of perennial ryegrass cultivars on milk yield and nitrogen utilization in grazing dairy cows. J. Dairy Sci. 89:3494-3500. http://dx.doi.org/10.3168/jds.S00220302(06)72388-8

Valente, T. N. P., E. Detmann, S. C. Valadares Filho, M. Cunha, A. C. Queiróz, and C. B. Sampaio. 2011. In situ estimation of indigestible compounds contents in cattle feed and feces using bags made from different textiles. Braz. J. Anim. Sci. 40:666-675. http:// dx.doi.org/10.1590/S1516-35982011000300027.

van Egmond, K. T. Bresser, and L. Bouwman. 2002. The European nitrogen case. Ambio 31:72-78. http://dx.doi.org/10.1579/00447447-31.2.72.

Verbic, J., X. B. Chen, N. A. Macleod, and E. R. Orskov. 1990. Excretion of purine derivatives by ruminants. Effect of microbial nucleic acid infusion on purine derivative excretion by steers. J. Agric. Sci. 114:243-248. http://dx.doi.org/10.1017/S0021859600072610.

Vonnahme, K. A., M. J. Zhu, P. P. Borowicz, T. W. Geary, B. W. Hess, L. P. Reynolds, J. S. Caton, W. J. Means, and S. P. Ford. 2007. Effect of early gestational undernutrition on angiogenic factor expression and vascularity in the bovine placentome. J. Anim. Sci. 85:2464-2472. http://dx.doi.org/10.2527/jas.2006-805. 